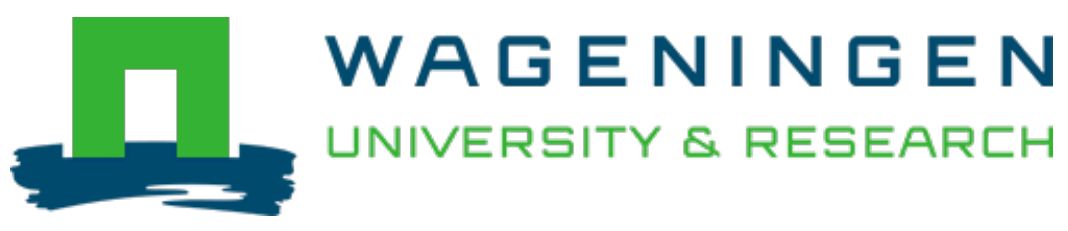

\title{
The relative importance of green infrastructure as refuge habitat for pollinators increases with local land-use intensity
}

\author{
Journal of Applied Ecology \\ Li, Pengyao; Kleijn, David; Badenhausser, Isabelle; Zaragoza-Trello, Carlos; Gross, Nicolas et al \\ https://doi.org/10.1111/1365-2664.13658
}

This article is made publicly available in the institutional repository of Wageningen University and Research, under the terms of article $25 \mathrm{fa}$ of the Dutch Copyright Act, also known as the Amendment Taverne. This has been done with explicit consent by the author.

Article 25 fa states that the author of a short scientific work funded either wholly or partially by Dutch public funds is entitled to make that work publicly available for no consideration following a reasonable period of time after the work was first published, provided that clear reference is made to the source of the first publication of the work.

This publication is distributed under The Association of Universities in the Netherlands (VSNU) 'Article $25 \mathrm{fa}$ implementation' project. In this project research outputs of researchers employed by Dutch Universities that comply with the legal requirements of Article $25 \mathrm{fa}$ of the Dutch Copyright Act are distributed online and free of cost or other barriers in institutional repositories. Research outputs are distributed six months after their first online publication in the original published version and with proper attribution to the source of the original publication.

You are permitted to download and use the publication for personal purposes. All rights remain with the author(s) and / or copyright owner(s) of this work. Any use of the publication or parts of it other than authorised under article $25 \mathrm{fa}$ of the Dutch Copyright act is prohibited. Wageningen University \& Research and the author(s) of this publication shall not be held responsible or liable for any damages resulting from your (re)use of this publication.

For questions regarding the public availability of this article please contact openscience.library@,wur.nl 


\title{
The relative importance of green infrastructure as refuge habitat for pollinators increases with local land-use intensity
}

\author{
Pengyao Li ${ }^{1,2}$ (1) | David Kleijn ${ }^{1}$ (i) | Isabelle Badenhausser, ${ }^{3,4,5}$ | Carlos Zaragoza-Trello ${ }^{6}$ \\ Nicolas Gross ${ }^{7}$ | Ivo Raemakers ${ }^{8}$ | Jeroen Scheper ${ }^{1}$ (ID
}

${ }^{1}$ Plant Ecology and Nature Conservation Group, Wageningen University, Wageningen, The Netherlands; ${ }^{2}$ College of Resources and Environmental Sciences, China Agricultural University, Beijing, China; ${ }^{3}$ Centre d'Etudes Biologiques de Chizé, Université de La Rochelle, Villiers en Bois, France; ${ }^{4}$ LTSER "ZA Plaine \& Val de Sèvre", CNRS, Villiers en Bois, France; ${ }^{5}$ Unité de Recherche Pluridisciplinaire Prairies Plantes Fourragères, INRA, Lusignan, France; ${ }^{6}$ Estación Biológica de Donãna (EBD-CSIC), Sevilla, Spain; ${ }^{7}$ Unité de Recherche sur l'Ecosystème Prairial, INRA, Université Clermont Auvergne, Clermont-Ferrand, France and

${ }^{8}$ Independent Amateur Entomologist, Maarheeze, The Netherlands

Correspondence

Jeroen Scheper

Email: Jeroen.Scheper@wur.nl

\section{Funding information}

Agence Nationale de la Recherche; China Scholarship Council, Grant/Award Number: 201806350119; Severo-Ochoa predoctoral fellowship, Grant/Award Number: SVP2014-068580; Nederlandse Organisatie voor Wetenschappelijk Onderzoek; BiodivERsA/FACCE-JPI; Ministerio de Economía y Competitividad

Handling Editor: Lorenzo Marini

\section{Abstract}

1. Agricultural expansion and intensification have resulted in strong declines in farmland biodiversity across Europe. In many intensively farmed landscapes, linear landscape elements such as field boundaries, road verges and ditch banks are the main remaining green infrastructures providing refuge for biodiversity, and as such play a pivotal role in agri-environmental policies aiming at mitigating biodiversity loss. Yet, while we have a fairly good understanding of how agricultural intensification influences biodiversity on farmland, little is known about whether and how local land-use intensity affects biodiversity in nearby linear landscape elements and how this affects their role as biodiversity refuge.

2. Focussing on pollinating insects, we examined the effects of local land-use intensity on biodiversity in agricultural fields and adjacent green infrastructures. In an intensively farmed area in south-western France, we selected 23 agricultural grasslands and nearby field boundaries along a gradient in grassland cutting frequency which acted as a proxy for land-use intensity. We analysed how grassland cutting frequency affects species richness, abundance and community composition of wild bees and hoverflies in the grasslands and neighbouring field boundaries, and whether these effects differ across habitat types and species groups.

3. Grassland cutting frequency negatively affected pollinator species richness and abundance in the grasslands, whereas pollinators in the neighbouring field boundaries were unaffected. These responses reflected the effects of cutting frequency on floral resources, with flower cover and richness decreasing in grasslands but not in field boundaries. As a result, the proportion of the local pollinator community supported by field boundaries increased with the increasing cutting frequency of the adjacent grassland.

4. Common and rare pollinator species generally showed similar responses. Furthermore, communities of plants and pollinators in field boundaries next to intensively farmed grasslands were fairly similar to those next to extensively farmed ones. 
5. Synthesis and applications. Our results suggest that, as nearby land use intensifies, flower-rich field boundaries become increasingly important as pollinator refuge habitats. Conserving field boundaries and other green infrastructures, and maintaining or enhancing their quality, therefore constitute important tools to conserve and promote pollinators in intensively farmed landscapes.

\section{KEYWORDS}

agri-environmental measures, field boundaries, flower resources, grassland, green infrastructure, hoverflies, land-use intensity, wild bees

\section{1 | INTRODUCTION}

Industrialization and rationalization of modern agriculture are sustaining the rapidly increasing world population (Lanz, Dietz, \& Swanson, 2018) but has been accompanied by unprecedented global biodiversity loss (Butchart et al., 2010; Green, Cornell, Scharlemann, $\&$ Balmford, 2005). In Europe, crop and non-crop habitats in agricultural landscapes have traditionally supported high levels of biodiversity (Bignal \& McCracken, 1996). However, agricultural expansion has increasingly resulted in loss and fragmentation of semi-natural habitats (Tscharntke, Klein, Kruess, Steffan-Dewenter, \& Thies, 2005). Furthermore, intensifying farming practices have made agricultural fields increasingly unsuitable for wild species of plants (Kleijn et al., 2009) and animals (Hendrickx et al., 2007). Only a limited set of species are able to persist on intensively farmed land, and this same set of species is found in agricultural fields across the continent (Flohre et al., 2011; Kleijn et al., 2015). In contemporary intensively farmed landscapes, the remaining wild species mainly occurs in the last few fragments of non-crop habitats, which often are linear landscape elements such as field boundaries, roadside verges and ditch banks (Marshall \& Moonen, 2002; Öckinger \& Smith, 2007).

While there is a fairly good understanding of how land-use intensity influences biodiversity on farmland, we know much less about whether and how local land-use intensity affects biodiversity in the surrounding linear landscape elements. These elements represent the main biodiversity refuge habitats in intensively farmed landscapes, containing overwintering locations, food resources, reproduction sites and dispersal corridors for many wild species (Carvalheiro, Seymour, Nicolson, \& Veldtman, 2012; Geiger, Wäckers, $\&$ Bianchi, 2009). Their importance for farmland biodiversity conservation has been acknowledged in agri-environmental policies. Most European countries provide subsidies for farmers to conserve and manage linear landscape elements as green infrastructures (Batary, Dicks, Kleijn, \& Sutherland, 2015). Agri-environment schemes (AES) targeting these green infrastructures are generally more effective than those targeting agricultural fields (Batary et al., 2015), and are more preferred by farmers, supposedly because they interfere less with farming practices (Kleijn et al., 2019). A better understanding of how biodiversity in green infrastructures responds to local land-use intensity could help design more effective conservation strategies and policy instruments to conserve biodiversity.
Here we examine how increasing land-use intensity of agricultural grasslands affects wild pollinator species richness, abundance and community composition in focal grasslands and neighbouring field boundaries. Wild pollinators are a key species group in farmland ecosystems. They play an important role in pollinating wild plants (Ollerton, Winfree, \& Tarrant, 2011) and crops (Klein et al., 2007), yet many species are threatened by land-use intensification (Potts et al., 2010). In Europe, extensively managed grasslands represent primary habitat for pollinators, particularly bees, because they provide both flowers and nesting sites (Öckinger \& Smith, 2007). However, most grasslands in European agricultural regions are used for intensive livestock farming (Vickery et al., 2001), field boundaries therefore often become the last relatively wide spread non-crop habitats for pollinators (Marshall \& Moonen, 2002).

Because pollinators are highly mobile organisms, land-use intensification of grassland could theoretically result in negative, neutral or positive responses of pollinators in field boundaries (Figure 1). This would largely depend on the disturbance levels and the spatial redistribution of local pollinator populations (Fijen, Scheper, Boekelo, Raemakers, \& Kleijn, 2019). Negative relationships could arise if habitat quality of field boundaries is degraded by increasing land-use intensity in the nearby agricultural fields (Öckinger \& Smith, 2007), such as physical damage by agricultural machinery, pesticide drift or fertilizer misplacement (Schmitz, Hahn, \& Brühl, 2014). In the most extreme case, pollinator diversity would decline at a rate similar to that in agricultural grasslands (Figure 1a). More likely, diversity will decline at a rate lower than that in grasslands (Figure 1b) because disturbance levels in the boundaries are generally lower than those in grasslands. Neutral responses may occur if habitat quality in field boundaries is unaffected by farming practices in neighbouring grasslands (Figure 1c) and pollinator densities in field boundaries have reached carrying capacity. Finally, pollinator diversity in field boundaries may increase in some cases (Figure 1d) when at low land-use intensity pollinator densities in field boudaries are below carrying capacity and increasing land-use intensity results in more pollinators seeking refuges in field boundaries (Tscharntke et al., 2012).

These responses may furthermore differ between species groups. For instance, bees are central place foragers, whereas hoverflies disperse freely through the landscape (Jauker, Diekötter, 

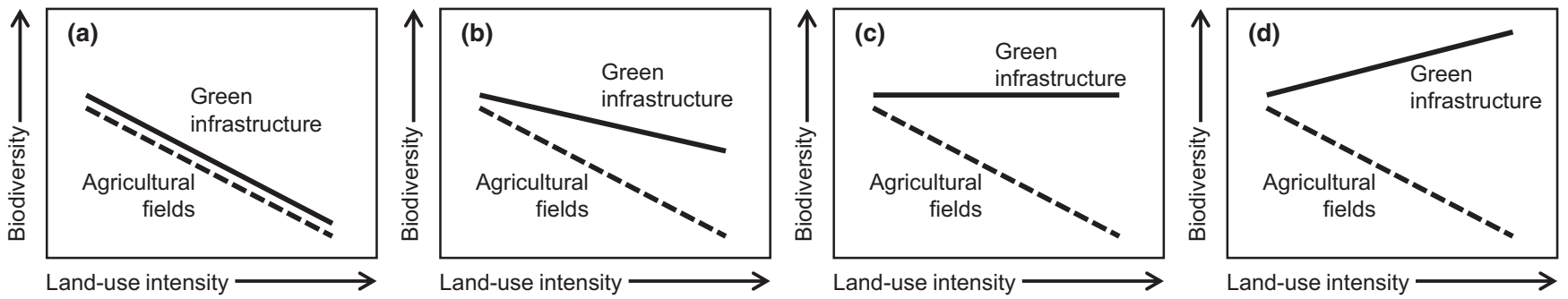

FIGURE 1 Hypothetical relationships between farming intensity and biodiversity in agricultural fields (dashed lines) and green infrastructures (solid lines). In agricultural fields biodiversity is negatively affected by farming intensity. In surrounding green infrastructures, effects may be similarly negative (a), less negative (b), neutral (c) or even positive (d)

Schwarzbach, \& Wolters, 2009). Furthermore, specialist or rare species are often more vulnerable than generalist or widespread species (Davies, Margules, \& Lawrence, 2004). Community composition may therefore change even when total abundance or richness remains constant, for example, because rare species disappear but generalist species increase. From a conservation perspective, the response of rare species is more interesting, but from a functional perspective, that is, the delivery of pollination services, the response of widespread species that dominate pollinator communities may be more relevant (Kleijn et al., 2015). Biodiversity conservation strategies, should therefore distinguish between the responses of these different species groups (Kleijn et al., 2006).

In this study, we used a space-for-time approach to examine the response of wild pollinators in grasslands and their nearby field boundaries to land-use intensity in grasslands. We surveyed wild bees and hoverflies, two key groups of wild pollinators (Jauker, Bondarenko, Becker, \& Steffan-Dewenter, 2012), in 23 pairs of field boundaries and nearby agricultural grasslands that covered a gradient in land-use intensity. We ask specifically:

1. How does pollinator biodiversity in agricultural grasslands and neighbouring field boundaries change with increasing local landuse intensity?

2. Do the observed relationships with local land-use intensity differ between species groups and does this result in changing species composition?

\section{2 | MATERIALS AND METHODS}

\section{1 | Landscape and site selection}

The study was conducted in the Long Term Socio-economic and Ecosystem Research platform Zone Atelier 'Plaine \& Val de Sèvre', a $435 \mathrm{~km}^{2}$ intensively farmed area in south-western France. The area is mainly used for arable and mixed-farming, with wheat (33.8\%), sunflower (10.4\%), maize (9.6\%), oilseed rape $(8.3 \%)$ and pea $(2 \%)$ as the main crops and grasslands comprising $13.5 \%$ of the area. Dominated by a karst landscape with calcareous rocks, this area contains shallow and poor alkaline soils with low water retention (Bretagnolle et al., 2018).
We selected 23 sites, each consisting of a grassland and a nearby field boundary. The minimum distance between grasslands was $0.9 \mathrm{~km}$ ( $M \pm S D: 1.8 \pm 1.0 \mathrm{~km}$; range: $0.9-4.0 \mathrm{~km}$ ). Grasslands covered a gradient in cutting frequency, ranging from one to four times per year. We used cutting frequency as a proxy of land-use intensity because it is the main disturbance in grasslands and it is generally correlated with fertilizer inputs (Hudewenz et al., 2012), another common indicator of agricultural land-use intensity (Herzog et al., 2006; Kleijn et al., 2009). Four of the five grasslands that were cut once a year were under AES. They were typically mulched and did not receive any chemical fertilizer. Grasslands that were cut two ( 9 grasslands), three (6 grasslands) or four ( 3 grasslands) times per year were managed for silage or hay. These grasslands received an average $\mathrm{N}$ input of $29.28 \mathrm{~kg} / \mathrm{ha}$ in 2015 but no pesticides. Only the grasslands that were cut four times per year received herbicides. Grasslands contained only herbaceous vegetation, while field boundaries generally contained both herbaceous and woody vegetation. Field boundaries were generally cut once or twice a year. All grassland-boundary pairs were located in intensively farmed structurally simple landscapes with similar proportions of arable land ( $M=79.74 \%$, range: $69.37 \%-89.89 \%$ ) within $1 \mathrm{~km}$ radius, a typical proportion of arable land in the landscape of the study region (Bretagnolle et al., 2018). The proportion of arable land in the landscape was not correlated with grassland cutting frequency (Table S1). This way, we prevented confounding effects of landscape context, which is known to moderate the effects of conservation management on local pollinator diversity (Scheper et al., 2013; Tscharntke et al., 2005).

\section{2 | Data collection}

\subsection{1 | Pollinator sampling}

We surveyed wild pollinators in four separate rounds from June to August in 2015 using standardized transect walks (Westphal et al., 2008) between 9.00 and $18.00 \mathrm{hr}$ on dry, sunny days with low wind speeds and temperatures above $15^{\circ} \mathrm{C}$. In each grassland or field boundary, we located two $2 \times 75 \mathrm{~m}$ transects. In field boundaries narrower than $2 \mathrm{~m}$, we applied two $1 \times 150 \mathrm{~m}$ transects instead. Transects were located in the most flower-rich areas of every grassland and field boundary because pollinators concentrate in flowerrich patches (Leiss \& Klinkhamer, 2005). In each transect per round, 
we surveyed wild bees and hoverflies for $15 \mathrm{~min}$. Easily recognizable species were generally identified to species level on sight in the field. Other species were collected and identified in the laboratory. We grouped Bombus terrestris and B. lucorum together and Halictus compressus, $H$. langobardicus and $H$. simplex as well, because in the study area they are indiscernible without molecular techniques.

\subsection{2 | Environmental variables}

After each pollinator survey, we quantified flower cover and flower species richness following an approach similar to that used by Scheper et al. (2015). We identified and recorded all plant species flowering in the transect and estimated flower cover of each species as: ((total number of flower units $\times$ the mean surface area of the flower unit)/the transect area) $\times 100 \%$. Total flower cover per transect per round was obtained by summing the cover of all species. Data on cutting frequency of grasslands in 2015 were collected through interviews conducted with farmers in early 2016. Finally, we calculated arable land cover in 2015 as a measure of landscape complexity (Martin et al., 2019) within radii of $500 \mathrm{~m}$ and $1 \mathrm{~km}$ of each pair by using ArcGIS 10.0 (ESRI) based on yearly land-use monitoring at the field scale over the study area (Bretagnolle et al., 2018).

\section{3 | Data analysis}

\subsection{1 | Pollinator abundance and species richness}

All analyses were performed using $\mathrm{R}$ version 3.6.0 (R Core Team, 2019). To address the first question, we analysed the effect of grassland cutting frequency on wild bee and hoverfly abundance and species richness in grasslands and field boundaries. We built general linear mixed models (GLMM, package GLMMTMB; Brooks et al., 2017) with suitable distribution and link function for each response (Table 1). These GLMMs included 'grassland cutting frequency', 'habitat' (grassland vs. field boundary) and their interaction as fixed factors, and study site and survey round as crossed random factors to account for paired design and repeated surveys. Although variation in arable land cover was relatively small (see Section 2.1), we included it as a covariate to correct for potential differences in landscape complexity. The analysis using semi-natural habitat cover generally explained lower variation in responses (Table S2) and produced similar results as those using arable land cover (Table S3). To help understand how grassland cutting frequency influences pollinators through floral resources, we analysed its effect on flower cover and richness using similar models as above but with flower cover and richness as response variables. In addition, we analysed the effect of local flower resources on pollinators using models that incorporated pollinator abundance and richness as response variables and flower cover and richness as explanatory variables, with 'arable land cover' as a covariate and study site and survey round as crossed random factors.

In all analyses, response variables were aggregated over the two transects per habitat at each site. To improve the balance of sampling, flower cover was square-root transformed and an outlier (a single habitat at a site in a round) with extremely high flower cover was excluded (Zuur, leno, \& Elphick, 2010). Analyses including the outlier produced qualitatively similar results. Full models were assessed for collinearity through variance inflation factors (VIFs; Draper \& Smith, 1998). The highest VIF value was 1.05, which is well below the threshold of 3 (Zuur, leno, \& Smith, 2007). Arable land

TABLE 1 Results for general linear mixed models examining the effects of grassland cutting frequency, habitat (grasslands or field boundaries) and their interaction on species richness and abundance of pollinators. Arable land cover in $500 \mathrm{~m}$ or $1 \mathrm{~km}$ is a covariate. Distribution and link function of GLMMs: G, Gaussian distribution with identity link function; GL, Gaussian distribution with log link function; NB, negative binomial distribution with log link function; P, Poisson distribution with log link function

\begin{tabular}{|c|c|c|c|c|c|c|c|c|c|c|c|c|}
\hline \multirow[b]{2}{*}{ Groups } & \multirow{2}{*}{$\begin{array}{l}\text { Diversity } \\
\text { index }\end{array}$} & \multirow{2}{*}{$\begin{array}{l}\text { Species } \\
\text { class }\end{array}$} & \multirow{2}{*}{$\begin{array}{l}\text { Distribution } \\
\text { and link } \\
\text { function }\end{array}$} & \multicolumn{3}{|c|}{ Arable land cover } & \multicolumn{2}{|c|}{$\begin{array}{l}\text { Grassland cutting } \\
\text { frequency }\end{array}$} & \multicolumn{2}{|c|}{ Habitat } & \multicolumn{2}{|c|}{$\begin{array}{l}\text { Grassland cutting } \\
\text { frequency: Habitat }\end{array}$} \\
\hline & & & & Radius & $\chi^{2}$ & $p$-value & $\chi^{2}$ & $p$-value & $\chi^{2}$ & $p$-value & $\chi^{2}$ & $p$-value \\
\hline \multirow[t]{5}{*}{ Wild bees } & \multirow{3}{*}{$\begin{array}{l}\text { Species } \\
\text { richness }\end{array}$} & Total & G & $500 \mathrm{~m}$ & 5.63 & 0.018 & 21.53 & $<0.001$ & 21.53 & $<0.001$ & 31.63 & $<0.001$ \\
\hline & & Rare & NB & $1 \mathrm{~km}$ & 7.65 & 0.006 & 3.46 & 0.063 & 6.22 & 0.013 & 19.16 & $<0.001$ \\
\hline & & Common & NB & $500 \mathrm{~m}$ & 3.10 & 0.078 & 3.46 & 0.063 & 18.53 & $<0.001$ & 33.39 & $<0.001$ \\
\hline & \multirow{2}{*}{ Abundance } & Rare & NB & $1 \mathrm{~km}$ & 6.36 & 0.012 & 1.52 & 0.217 & 1.56 & 0.211 & 13.12 & $<0.001$ \\
\hline & & Common & NB & $500 \mathrm{~m}$ & 0.55 & 0.458 & 1.91 & 0.167 & 6.50 & 0.011 & 23.13 & $<0.001$ \\
\hline \multirow[t]{3}{*}{ Hoverflies } & \multirow{3}{*}{$\begin{array}{l}\text { Species } \\
\text { richness }\end{array}$} & Total & $\mathrm{P}$ & $1 \mathrm{~km}$ & 0.55 & 0.459 & 0.00 & 0.997 & 4.17 & $<0.001$ & 4.66 & 0.031 \\
\hline & & Rare & NB & $1 \mathrm{~km}$ & 0.51 & 0.474 & 0.37 & 0.545 & 13.92 & $<0.001$ & 0.01 & 0.908 \\
\hline & & Common & $\mathrm{P}$ & $1 \mathrm{~km}$ & 0.24 & 0.622 & 0.78 & 0.377 & 17.87 & $<0.001$ & 3.72 & 0.054 \\
\hline
\end{tabular}

Significant effects $(p<0.05)$ are shown in bold. 
cover radius ( $500 \mathrm{~m}$ or $1 \mathrm{~km}$ ) of each model was determined by comparing model fit using package MuMIN (Bartoń, 2019) and the one producing the lower AICc was included (Table S2). Full models were manually simplified by backward elimination of non-significant factors. We assessed the significance of each fixed factor and covariate using likelihood-ratio tests.

\subsection{2 | Pollinator species composition}

To answer the second question, we firstly classified species into rare and common species according to their proportional abundance in this study. We did this separately for wild bees and hoverflies. Only the pollinator individuals identified to species level were included. Species accounting for $<1.0 \%$ of the total number of individuals were classified as rare species (Kleijn et al., 2009), the other species were considered as common species. We subsequently analysed how abundance and richness of the two species classes responded to grassland cutting frequency using the same approach and models as above.

To further analyse whether grassland cutting frequency affected species composition, we examined whether communities became less similar with increasing cutting frequency. We did this by, firstly, randomly choosing a reference grassland from those with the lowest cutting frequency (once a year). The field boundary adjacent to this reference grassland was considered as the reference field boundary. We then used the VEGAN package (Oksanen et al., 2019) to calculate Bray-Curtis community similarity index based on abundance data of each species in each habitat per site for three comparisons: (a) between each field boundary and the reference field boundary; (b) between each grassland and the reference grassland; (c) between each grassland and its adjacent field boundary. Two sites were not included in this analysis because they were surveyed less than four rounds. Similarity indexes for flowers, wild bees and hoverflies were calculated separately. We built linear models with the different similarity indexes as response variables, 'grassland cutting frequency' as a fixed factor, and 'arable land cover' (radii determined by AICc) as a covariate.

\section{RESULTS}

\section{1 | Flower abundance and species richness}

We recorded 139 species of flowering plants in total. In grasslands, the most abundant flower family was Fabaceae (38\% of the total flower cover). In field boundaries, Fabaceae only accounted for 4.74\%, whereas Apiaceae was most abundant (52.82\%, Figure S1). The effects of grassland cutting frequency on flower cover and richness differed between habitat types (Figure S2; flower species richness: interaction grassland cutting frequency $\times$ habitat $\chi^{2}=59.85$, $p<0.001$; flower cover: $\chi^{2}=20.98, p<0.001$ ). In grasslands, increasing cutting frequency significantly decreased both flower species richness $(\beta=-0.54, z=-7.43, p<0.001)$ and flower $\operatorname{cover}(\beta=-0.22$, $z=-3.56, p<0.001)$, while in the adjacent field boundaries, flower species richness $(\beta=0.04, z=0.65, p=0.517)$ and flower cover ( $\beta=0.09, z=1.44, p=0.151)$ were not affected.

\section{2 | Pollinator abundance and species richness}

In total, we recorded 4,377 wild bee individuals comprising 102 species, and 922 hoverfly individuals comprising 30 species. The most frequently observed wild bee species were Lasioglossum subhirtum (1,054 individuals), Lasioglossum malachurum (436) and Lasioglossum pauxillum (404), whereas Sphaerophoria scripta (482 individuals), Episyrphus balteatus (107) and Melanostoma mellinum (99) were the most frequently observed hoverfly species. Similar to the flowers, pollinator responses to grassland cutting frequency differed between habitat types (Table 1; Figures 2a,d and 3a,d). In grasslands, increasing cutting frequency resulted in significant decreases in $(b, e)$ and common wild bees (c, $f$ ) in fie boundaries (red) and grasslands (blue). Asterisks denote significance of grassland cutting frequency $\times$ habitat interactions: ${ }^{*} p<0.05 ;{ }^{* *} p<0.01 ;{ }^{* * *} p<0.001$. Solid lines denote significant $(p<0.05)$ habitatspecific regression coefficients for the effect of grassland cutting frequency, and dashed lines denote non-significant $(p \geq 0.05)$ regression coefficients. Shaded areas indicate $95 \%$ confidence intervals

Habitats (a) Wild bee richness

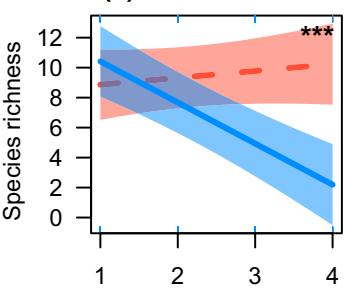

(d) Wild bee abundance

(b) Rare wild bee richness

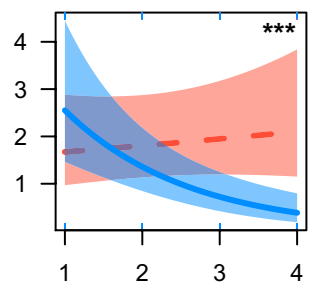

(e) Rare wild bee abundance

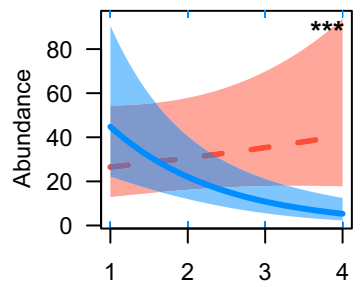

(c) Common wild bee richness

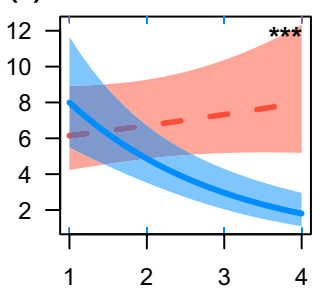

(f) Common wild bee abundance

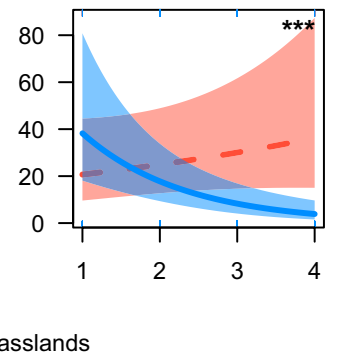

Grassland cutting frequency (year) 
(a) Hoverfly richness

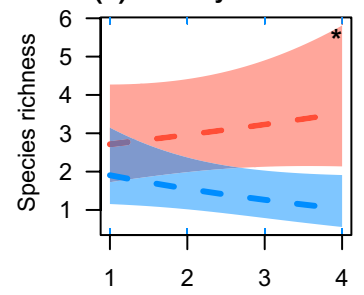

(d) Hoverfly abundance

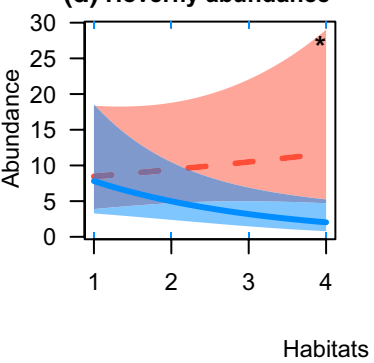

(b) Rare hoverfly richness

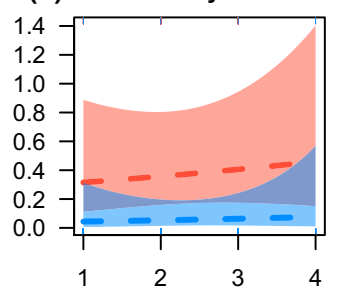

(e) Rare hoverfly abundance

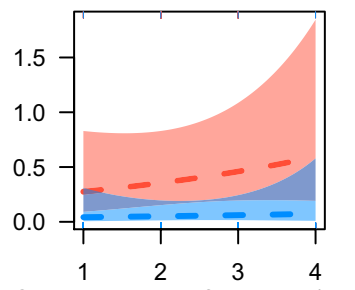

(c) Common hoverfly richness

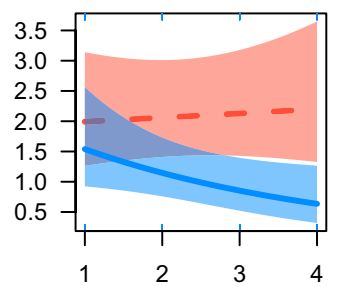

(f) Common hoverfly abundance

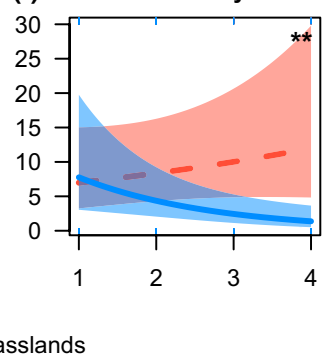

FIGURE 3 Effects of grassland cutting frequency on species richness $(a-c)$ and abundance (d-f) of all (a, d), rare (b, e) and common hoverflies (c, $f$ ) in field boundaries (red) and grasslands (blue). Asterisks denote significance of grassland cutting frequency $\times$ habitat interactions: ${ }^{*} p<0.05 ;{ }^{* *} p<0.01 ;{ }^{* * *} p<0.001$. Solid lines denote significant $(p<0.05)$ habitatspecific regression coefficients for the effect of grassland cutting frequency, and dashed lines denote non-significant $(p \geq 0.05)$ regression coefficients. Shaded areas indicate $95 \%$ confidence intervals

\begin{tabular}{|c|c|c|c|c|c|c|}
\hline & \multirow[b]{2}{*}{ Group } & \multicolumn{2}{|c|}{$\begin{array}{l}\text { Grassland cutting } \\
\text { frequency }\end{array}$} & \multicolumn{3}{|c|}{ Arable land cover } \\
\hline & & $F$ & $p$ & Radius & $F$ & $p$ \\
\hline \multirow[t]{3}{*}{ (a) $\mathrm{FB}_{\mathrm{i}}-\mathrm{FB}_{\mathrm{R}}$} & Flowers & 0.10 & 0.753 & $1 \mathrm{~km}$ & 0.47 & 0.499 \\
\hline & Wild bees & 0.503 & 0.487 & $1 \mathrm{~km}$ & 0.25 & 0.623 \\
\hline & Hoverflies & 1.170 & 0.293 & $1 \mathrm{~km}$ & 0.62 & 0.440 \\
\hline \multirow[t]{3}{*}{ (b) $G R_{i}-G R_{R}$} & Flowers & 9.855 & 0.005 & $500 \mathrm{~m}$ & 1.377 & 0.256 \\
\hline & Wild bees & 5.519 & 0.030 & $500 \mathrm{~m}$ & 0.146 & 0.707 \\
\hline & Hoverflies & 1.371 & 0.256 & $500 \mathrm{~m}$ & 0.853 & 0.368 \\
\hline \multirow[t]{3}{*}{ (c) $\mathrm{FB}_{\mathrm{i}}-\mathrm{GR}_{\mathrm{R}}$} & Flowers & 6.200 & 0.022 & $1 \mathrm{~km}$ & 1.87 & 0.188 \\
\hline & Wild bees & 3.153 & 0.092 & $1 \mathrm{~km}$ & 0.11 & 0.743 \\
\hline & Hoverflies & 0.24 & 0.630 & $1 \mathrm{~km}$ & 1.20 & 0.286 \\
\hline
\end{tabular}

TABLE 2 Results of linear models examining the effects of grassland cutting frequency on the pairwise community similarity of flowers and pollinators between (a) each field boundary and the reference field boundary, (b) each grassland and the reference grassland, (c) each field boundary-grassland pair. Arable land cover was included as a covariate, with the radius determined by $\mathrm{AICC}$

Significant effects $(p<0.05)$ are shown in bold.

wild bee species richness ( $\beta=-2.74, z=-5.42, p<0.001$ ), wild bee abundance $(\beta=-0.71, z=-4.39, p<0.001)$, hoverfly abundance $(\beta=-0.45, z=-2.48, p=0.013)$ and a negative trend in hoverfly species richness ( $\beta=-0.20, z=-1.56, p=0.119)$. In contrast, in the neighbouring field boundaries, wild bee species richness ( $\beta=0.46$, $z=0.90, p=0.367)$, wild bee abundance $(\beta=0.14, z=0.97, p=0.332)$, hoverfly species richness ( $\beta=0.09, z=0.97, p=0.330$ ) and hoverfly abundance ( $\beta=0.11, z=0.67, p=0.504$ ) were not affected. Species richness and abundance of wild bees and hoverflies were positively related to flower species richness and flower cover (Table S4; Figures S3 and S4). Wild bee species richness was negatively affected by arable land cover within 500 m (Table 1; Figure S5).

\subsection{Common and rare species and species composition}

About 87 wild bee species and 20 hoverfly species were classified as rare species. In contrast, only 14 wild bee species and 7 hoverfly species were common species, however, they compromised $73.36 \%$ of total wild bee individuals and $79.34 \%$ of total hoverfly individuals. Common and rare wild bees showed similar response patterns to total wild bees (Tables 1; Figure 2; Table S3; Figures S3 and S4), although rare wild bee abundance showed an additional negative relationship with arable land cover in $1 \mathrm{~km}$ (Table 1; Figure S4). Common hoverflies showed similar response patterns as total hoverflies, but rare hoverflies displayed differential responses (Table 1; Figure 3). Richness and abundance of rare hoverflies were not affected by grassland cutting frequency in field boundaries and in grasslands but were significantly higher in field boundaries than in grasslands across the entire intensity gradient.

Relative to the reference field boundary, similarity of flower, wild bee and hoverfly communities in other field boundaries was not affected by grassland cutting frequency (Table 2; Figure 4a-c). In contrast, with increasing cutting frequency, flower and wild bee communities in grasslands became less similar to those in the reference grassland, although grassland hoverfly communities did not (Table 2; Figure 4d-f). The communities of flowering plants of 
FIGURE 4 Effects of grassland cutting frequency on community similarity of flowers, wild bees and hoverflies. Panel $(a-c)$, pairwise similarity between each field boundary and the reference field boundary; panel ( $d-f)$, pairwise similarity between each grassland and the reference grassland; panel (g-i), pairwise similarity between each grassland-field boundary pair. Solid lines denote significant effects of grassland cutting frequency $(p<0.05)$; dashed lines denote non-significant effects $(p \geq 0.05)$. Plotted points show back-transformed partial residuals. Shaded areas indicate $95 \%$ confidence intervals (a) Flowers $\left(\mathrm{FB}_{\mathrm{i}}-\mathrm{FB}_{\mathrm{R}}\right)$

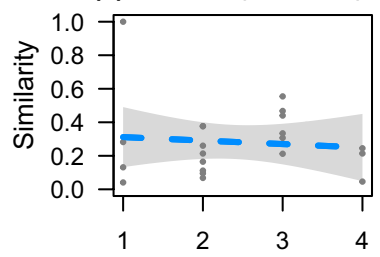

(d) Flowers $\left(G_{R_{i}}-G_{R}\right)$

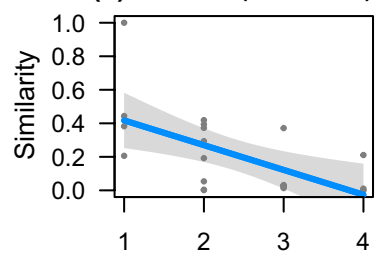

(g) Flowers $\left(\mathrm{FB}_{\mathrm{i}}-\mathrm{GR}_{\mathrm{i}}\right)$

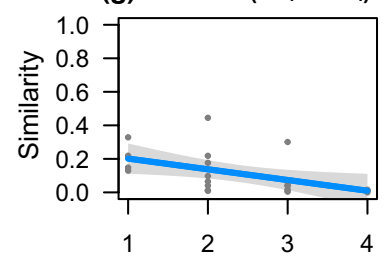

(b) Wild bees $\left(\mathrm{FB}_{\mathrm{i}}-\mathrm{FB}_{\mathrm{R}}\right)$

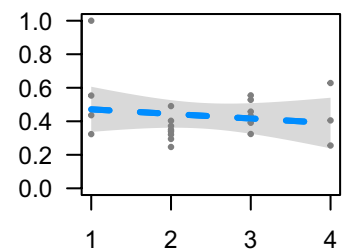

(e) Wild bees $\left(G R_{i}-G R_{R}\right)$

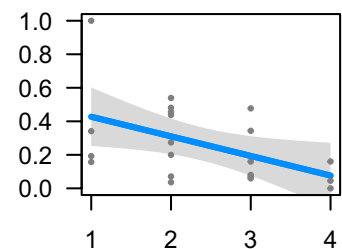

(h) Wild bees $\left(F B_{i}-G_{i}\right)$

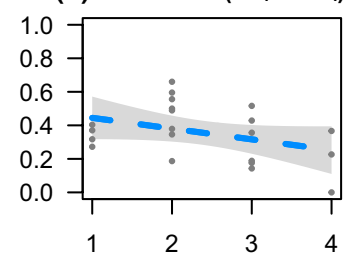

Grassland cutting frequency (year) (c) Hoverflies $\left(\mathrm{FB}_{\mathrm{i}}-\mathrm{FB}_{\mathrm{R}}\right)$

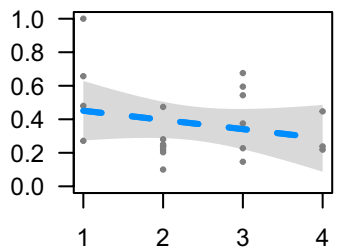

(f) Hoverflies $\left(G R_{i}-G R_{R}\right)$

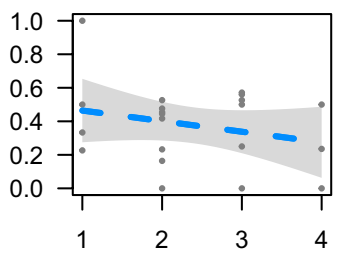

(i) Hoverflies $\left(\mathrm{FB}_{\mathrm{i}}-\mathrm{GR}_{\mathrm{i}}\right)$

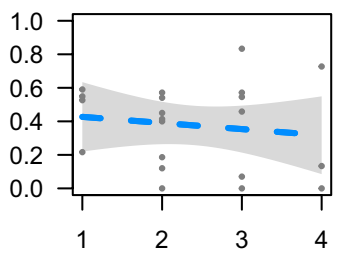

adjoining grasslands and field boundaries became increasingly dissimilar with increasing grassland cutting frequency. Similarity of wild bee communities in pairs of field boundaries and neighbouring grasslands tended to decrease with cutting frequency, whereas hoverfly communities were not affected (Table 2; Figure 4g-i). Arable land cover did not affect community similarity of flowers, wild bees and hoverflies in any of the analyses (Table 2).

\section{4 | DISCUSSION}

Linear landscape elements are a key component of green infrastructure in intensively farmed landscapes and play a pivotal role in agrienvironmental policies targeting biodiversity loss (Pe'er et al., 2017). Whether and how wildlife communities in these landscape elements change as the surrounding land-use intensifies is still poorly understood. Here we examined the effect of land-use intensity in grassland on wild pollinators in agricultural grasslands and neighbouring field boundaries. We found that, in the grasslands, richness and abundance of wild bees and hoverflies decreased with increasing land-use intensity, whereas those in the neighbouring field boundaries were unaffected. These patterns were generally consistent for common and rare pollinator species, with the exception of rare hoverflies, which displayed higher richness and abundance in field boundaries across the entire intensity gradient.

Many studies report negative relationships between landuse intensity and pollinator diversity in productive fields (Ekroos et al., 2020; Weiner, Werner, Linsenmair, \& Blüthgen, 2011) or at the interface between agricultural and semi-natural habitats (Hendrickx et al., 2007; Le Féon et al., 2010). Perhaps a bit surprisingly, our study shows that pollinator richness and abundance in field boundaries were unrelated to cutting frequency in neighbouring grasslands, even though they declined with increasing cutting frequency in the grasslands themselves (i.e. scenario Figure 1c). These species groups were strongly positively related to floral resources (Table S4; Figures S3 and S4), as found in many studies (Lucas, Bull, de Vere, Neyland, \& Forman, 2017; Scheper et al., 2015; Sutter et al., 2017). Furthermore, in our study area, field boundaries were generally cut no more than twice a year. Flower richness, cover or composition in the field boundaries were not affected by grassland cutting frequency (Figure 4a; Figure S2). This suggests that pollinator diversity and abundance in linear landscape elements is primarily determined by resource availability in the element itself and is relatively unaffected by resource availability in the surrounding landscape.

Interestingly, abundance and richness of common and rare wild bees showed similar responses to grassland cutting frequency and, possibly because of this, community composition in field boundaries was not influenced by grassland cutting frequency as well (Figure 4). This is seemingly at odds with the general pattern that rare species are more susceptible to land-use change than common species (Harrison, Gibbs, \& Winfree, 2019; Sykes, Santini, Etard, \& Newbold, in press). However, if bee community composition is predominantly influenced by local habitat quality, as our results suggest, this finding makes sense since the quality of the boundary habitat was not affected by land-use intensification in neighbour grasslands. Rare hoverflies showed differential response patterns, as they were not affected by grassland cutting frequency in either habitat types, possibly because they were observed in very low numbers (Figure 3b,e). We did, however, find higher rare hoverfly richness and abundance in field boundaries than in grasslands, possibly because field boundaries provided more suitable flower resources for hoverflies (more Apiaceae and less Fabacea) than grasslands (Lucas et al., 2017), and 
contained woody vegetation which is important for foraging, resting and larval habitat of hoverflies (Power, Jackson, Stout, Stewart, \& Gilbert, 2016).

Interestingly, at high land-use intensities, richness and densities of bees, hoverflies and flower plants were significantly higher in field boundaries than in grasslands, but at the lowest intensity, they were similar between habitat types (i.e. overlapping confidence intervals). This suggests that with ongoing farmland intensification, field boundaries and probably green infrastructure in general, become increasingly important pollinator refuges. Furthermore, these refuges can maintain diverse pollinator communities even in intensively farmed landscapes as long as they provide good quality habitat. Maintaining or enhancing the flower diversity and cover in existing field boundaries and other non-cultivated habitats could thus increase their carrying capacity and boost wild pollinator conservation in agricultural landscapes (Noordijk, Delille, Schaffers, \& Sýkora, 2009; Scheper et al., 2015). Pollinator-friendly management of the existing green infrastructure is probably more cost-effective but receives much less attention than establishment of new and often temporary landscape elements such as wildflower strips (Scheper et al., 2013; Sutter et al., 2017). From a methodological point of view, our findings support the approaches proposed by Kleijn et al. (2018) to estimate landscape-level pollinator population size through multiplying the densities of pollinators in a certain habitat with the cover of that habitat in a landscape. Here we find that pollinator densities in one habitat are not influenced by the quality of neighbouring habitats but are mainly determined by the characteristics of the habitat itself. This considerably improves the reliability of extrapolating observed local densities to landscape-level pollinator population size estimates. It furthermore suggests that effects of different habitats on landscape-level population sizes are additive rather than interactive.

\section{ACKNOWLEDGEMENTS}

We thank all farmers for granting access to their fields and for providing information on farming practices. We also thank Martijn Terpstra and Nick Hiofland for their assistance with field work. This research was funded through the 2013-2014 BiodivERsA/FACCEJPI joint call for research proposals (project ECODEAL), with the national funders MINECO, ANR and NWO. C.Z.-T. was supported by a Severo-Ochoa predoctoral fellowship SVP-2014-068580. P.L. was also supported by China Scholarship Council.

\section{AUTHORS' CONTRIBUTIONS}

D.K. and J.S. conceived the study; I.B., N.G., C.Z.-T. and J.S. collected data; I.R. idenitified the pollinators; P.L. analysed the data; P.L., D.K. and J.S. wrote the first draft of the manuscript. All authors contributed substantially to revisions of the manuscript and gave final approval for its publication.

\section{DATA AVAILABILITY STATEMENT}

Data are available via the Dryad Digital Repository: https://doi.org/ 10.5061/dryad.tdz08kpws (Li et al., 2020).

\section{ORCID}

Pengyao Li (iD https://orcid.org/0000-0002-8867-7520

David Kleijn (iD https://orcid.org/0000-0003-2500-7164

Carlos Zaragoza-Trello iD https://orcid.org/0000-0002-6824-3143

Jeroen Scheper (iD https://orcid.org/0000-0002-4314-996X

\section{REFERENCES}

Bartoń, K. (2019). MuMIn: Multi-Model Inference. R package version 1.43.15. Retrieved from https://CRAN.R-project.org/package=MuMln

Batary, P., Dicks, L. V., Kleijn, D., \& Sutherland, W. J. (2015). The role of agri-environment schemes in conservation and environmental management. Conservation Biology, 29, 1006-1016. https://doi.org/ 10.1111/cobi.12536

Bignal, E. M., \& McCracken, D. I. (1996). Low-intensity farming systems in the conservation of the countryside. Journal of Applied Ecology, 33, 413-424. https://doi.org/10.2307/2404973

Bretagnolle, V., Berthet, E., Gross, N., Gauffre, B., Plumejeaud, C., Houte, S., ... Gaba, S. (2018). Towards sustainable and multifunctional agriculture in farmland landscapes: Lessons from the integrative approach of a French LTSER platform. Science of the Total Environment, 627, 822-834. https://doi.org/10.1016/j.scitotenv.2018.01.142

Brooks, M. E., Kristensen, K., Van Benthem, K. J., Magnusson, A., Berg, C. W., Nielsen, A., ... Bolker, B. M. (2017). glmmTMB balances speed and flexibility among packages for zero-inflated generalized linear mixed modeling. The R Journal, 9(2), 378-400. https://doi.org/ 10.32614/RJ-2017-066

Butchart, S. H. M., Walpole, M., Collen, B., van Strien, A., Scharlemann, J. P. W., Almond, R. E. A., ... Watson, R. (2010). Global biodiversity: Indicators of recent declines. Science, 328, 1164-1168. https://doi. org/10.1126/science.1187512

Carvalheiro, L. G., Seymour, C. L., Nicolson, S. W., \& Veldtman, R. (2012). Creating patches of native flowers facilitates crop pollination in large agricultural fields: Mango as a case study. Journal of Applied Ecology, 49, 1373-1383. https://doi.org/10.1111/j.1365-2664.2012.02217.x

Davies, K. F., Margules, C. R., \& Lawrence, J. F. (2004). A synergistic effect puts rare, specialized species at greater risk of extinction. Ecology, 85, 265-271. https://doi.org/10.1890/03-0110

Draper, N. R., \& Smith, H. (1998). Applied regression analysis. New York, NY: John Wiley \& Sons.

Ekroos, J., Kleijn, D., Batáry, P., Albrecht, M., Báldi, A., Blüthgen, N., ... Smith, H. G. (2020). High land-use intensity in grasslands constrains wild bee species richness in Europe. Biological Conservation, 241, 108255. https://doi.org/10.1016/j.biocon.2019.108255

Fijen, T. P. M., Scheper, J. A., Boekelo, B., Raemakers, I., \& Kleijn, D. (2019). Effects of landscape complexity on pollinators are moderated by pollinators' association with mass-flowering crops. Proceedings of the Royal Society B: Biological Sciences, 286, 20190387. https://doi. org/10.1098/rspb.2019.0387

Flohre, A., Fischer, C., Aavik, T., Bengtsson, J., Berendse, F., Bommarco, R., ... Eggers, S. (2011). Agricultural intensification and biodiversity partitioning in European landscapes comparing plants, carabids, and birds. Ecological Applications, 21, 1772-1781.

Geiger, F., Wäckers, F. L., \& Bianchi, F. J. (2009). Hibernation of predatory arthropods in semi-natural habitats. BioControl, 54, 529-535.

Green, R. E., Cornell, S. J., Scharlemann, J. P., \& Balmford, A. (2005). Farming and the fate of wild nature. Science, 307, 550-555. https:// doi.org/10.1126/science.1106049

Harrison, T., Gibbs, J., \& Winfree, R. (2019). Anthropogenic landscapes support fewer rare bee species. Landscape Ecology, 34, 967-978. https://doi.org/10.1007/s10980-017-0592-x

Hendrickx, F., Maelfait, J.-P., Van Wingerden, W., Schweiger, O., Speelmans, M., Aviron, S., ... Bugter, R. O. B. (2007). How landscape structure, land-use intensity and habitat diversity affect components 
of total arthropod diversity in agricultural landscapes. Journal of Applied Ecology, 44, 340-351. https://doi.org/10.1111/j.1365-2664. 2006.01270.x

Herzog, F., Steiner, B., Bailey, D., Baudry, J., Billeter, R., Bukácek, R., ... Bugter, R. (2006). Assessing the intensity of temperate European agriculture at the landscape scale. European Journal of Agronomy, 24, 165-181. https://doi.org/10.1016/j.eja.2005.07.006

Hudewenz, A., Klein, A.-M., Scherber, C., Stanke, L., Tscharntke, T., Vogel, A., ... Ebeling, A. (2012). Herbivore and pollinator responses to grassland management intensity along experimental changes in plant species richness. Biological Conservation, 150, 42-52.

Jauker, F., Bondarenko, B., Becker, H. C., \& Steffan-Dewenter, I. (2012). Pollination efficiency of wild bees and hoverflies provided to oilseed rape. Agricultural and Forest Entomology, 14, 81-87. https://doi. org/10.1111/j.1461-9563.2011.00541.x

Jauker, F., Diekötter, T., Schwarzbach, F., \& Wolters, V. (2009). Pollinator dispersal in an agricultural matrix: Opposing responses of wild bees and hoverflies to landscape structure and distance from main habitat. Landscape Ecology, 24, 547-555. https://doi.org/10.1007/s10980-0099331-2

Kleijn, D., Baquero, R. A., Clough, Y., Diaz, M., De Esteban, J., Fernandez, F., ... Yela, J. L. (2006). Mixed biodiversity benefits of agri-environment schemes in five European countries. Ecology Letters, 9, 243-254; discussion 254-257. https://doi.org/10.1111/j.1461-0248.2005.00869.x

Kleijn, D., Bommarco, R., Fijen, T. P. M., Garibaldi, L. A., Potts, S. G., \& van der Putten, W. H. (2019). Ecological intensification: Bridging the gap between science and practice. Trends in Ecology \& Evolution, 34, 154-166. https://doi.org/10.1016/j.tree.2018.11.002

Kleijn, D., Kohler, F., Baldi, A., Batary, P., Concepcion, E. D., Clough, Y., ... Verhulst, J. (2009). On the relationship between farmland biodiversity and land-use intensity in Europe. Proceedings of the Royal Society B: Biological Sciences, 276, 903-909. https://doi.org/10.1098/ rspb.2008.1509

Kleijn, D., Linders, T. E. W., Stip, A., Biesmeijer, J. C., Wäckers, F. L., Bukovinszky, T., \& Carvalheiro, L. (2018). Scaling up effects of measures mitigating pollinator loss from local- to landscape-level population responses. Methods in Ecology and Evolution, 9, 1727-1738. https://doi.org/10.1111/2041-210X.13017

Kleijn, D., Winfree, R., Bartomeus, I., Carvalheiro, L. G., Henry, M., Isaacs, R., ... Potts, S. G. (2015). Delivery of crop pollination services is an insufficient argument for wild pollinator conservation. Nature Communications, 6, 7414. https://doi.org/10.1038/ncomms8414

Klein, A. M., Vaissiere, B. E., Cane, J. H., Steffan-Dewenter, I., Cunningham, S. A., Kremen, C., \& Tscharntke, T. (2007). Importance of pollinators in changing landscapes for world crops. Proceedings of the Royal Society B: Biological Sciences, 274, 303-313. https://doi. org/10.1098/rspb.2006.3721

Lanz, B., Dietz, S., \& Swanson, T. (2018). The expansion of modern agriculture and global biodiversity decline: An integrated assessment. Ecological Economics, 144, 260-277. https://doi.org/10.1016/j.ecole con.2017.07.018

Le Féon, V., Schermann-Legionnet, A., Delettre, Y., Aviron, S., Billeter, R., Bugter, R., ... Burel, F. (2010). Intensification of agriculture, landscape composition and wild bee communities: A large scale study in four European countries. Agriculture, Ecosystems \& Environment, 137, 143-150. https://doi.org/10.1016/j.agee.2010.01.015

Leiss, K. A., \& Klinkhamer, P. G. L. (2005). Spatial distribution of nectar production in a natural Echium vulgare population: Implications for pollinator behaviour. Basic and Applied Ecology, 6, 317-324. https:// doi.org/10.1016/j.baae.2005.02.006

Li, P., Kleijn, D., Badenhausser, I., Zaragoza-Trello, C., Gross, N., Raemakers, I., \& Scheper, J. (2020). Data from: The relative importance of green infrastructure as refuge habitat for pollinators increases with local land-use intensity. Dryad Digital Respository, https://doi.org/10.5061/dryad.tdz08kpws
Lucas, A., Bull, J. C., de Vere, N., Neyland, P. J., \& Forman, D. W. (2017). Flower resource and land management drives hoverfly communities and bee abundance in seminatural and agricultural grasslands. Ecology and Evolution, 7, 8073-8086. https://doi.org/10.1002/ece3.3303

Marshall, E., \& Moonen, A. (2002). Field margins in northern Europe: Their functions and interactions with agriculture. Agriculture, Ecosystems \& Environment, 89, 5-21. https://doi.org/10.1016/S0167 -8809(01)00315-2

Martin, E. A., Dainese, M., Clough, Y., Baldi, A., Bommarco, R., Gagic, V., ... Steffan-Dewenter, I. (2019). The interplay of landscape composition and configuration: New pathways to manage functional biodiversity and agroecosystem services across Europe. Ecology Letters, 22, 1083-1094. https://doi.org/10.1111/ele.13265

Noordijk, J., Delille, K., Schaffers, A. P., \& Sýkora, K. V. (2009). Optimizing grassland management for flower-visiting insects in roadside verges. Biological Conservation, 142, 2097-2103. https://doi.org/10.1016/j. biocon.2009.04.009

Öckinger, E., \& Smith, H. G. (2007). Semi-natural grasslands as population sources for pollinating insects in agricultural landscapes. Journal of Applied Ecology, 44, 50-59. https://doi.org/10.1111/j.1365-2664. 2006.01250.x

Oksanen, J., Blanchet, F. G., Friendly, M., Kindt, R., Legendre, P., McGlinn, D., ... Wagner, H. (2019). vegan: Community Ecology Package. R package version 2.5-6. Version, 2. Retrieved from https://CRAN.R-project. org/package=vegan

Ollerton, J., Winfree, R., \& Tarrant, S. (2011). How many flowering plants are pollinated by animals? Oikos, 120, 321-326. https://doi. org/10.1111/j.1600-0706.2010.18644.x

Pe'er, G., Zinngrebe, Y., Hauck, J., Schindler, S., Dittrich, A., Zingg, S., ... Lakner, S. (2017). Adding some green to the greening: Improving the EU's ecological focus areas for biodiversity and farmers. Conservation Letters, 10, 517-530. https://doi.org/10.1111/conl.12333

Potts, S. G., Biesmeijer, J. C., Kremen, C., Neumann, P., Schweiger, O., \& Kunin, W. E. (2010). Global pollinator declines: Trends, impacts and drivers. Trends in Ecology \& Evolution, 25, 345-353. https://doi. org/10.1016/j.tree.2010.01.007

Power, E. F., Jackson, Z., Stout, J. C., Stewart, A., \& Gilbert, F. (2016). Organic farming and landscape factors affect abundance and richness of hoverflies (Diptera, Syrphidae) in grasslands. Insect Conservation and Diversity, 9, 244-253. https://doi.org/10.1111/icad.12163

R Core Team. (2019). R: A language and environment for statistical computing. Vienna, Austria: R Foundation for Statistical Computing. R version, 3.6.0.

Scheper, J., Bommarco, R., Holzschuh, A., Potts, S. G., Riedinger, V., Roberts, S. P. M., ... Diamond, S. (2015). Local and landscape-level floral resources explain effects of wildflower strips on wild bees across four European countries. Journal of Applied Ecology, 52, 11651175. https://doi.org/10.1111/1365-2664.12479

Scheper, J., Holzschuh, A., Kuussaari, M., Potts, S. G., Rundlof, M., Smith, H. G., \& Kleijn, D. (2013). Environmental factors driving the effectiveness of European agri-environmental measures in mitigating pollinator loss - A meta-analysis. Ecology Letters, 16, 912-920. https:// doi.org/10.1111/ele.12128

Schmitz, J., Hahn, M., \& Brühl, C. A. (2014). Agrochemicals in field margins - An experimental field study to assess the impacts of pesticides and fertilizers on a natural plant community. Agriculture, Ecosystems \& Environment, 193, 60-69. https://doi.org/10.1016/j.agee.2014.04.025

Sutter, L., Jeanneret, P., Bartual, A. M., Bocci, G., Albrecht, M., \& Maclvor, S. (2017). Enhancing plant diversity in agricultural landscapes promotes both rare bees and dominant crop-pollinating bees through complementary increase in key floral resources. Journal of Applied Ecology, 54, 1856-1864. https://doi.org/10.1111/1365-2664.12907

Sykes, L., Santini, L., Etard, A., \& Newbold, T. (in press). Effects of rarity form on species' responses to land use. Conservation Biology. https:// doi.org/10.1111/cobi.13419 
Tscharntke, T., Klein, A. M., Kruess, A., Steffan-Dewenter, I., \& Thies, C. (2005). Landscape perspectives on agricultural intensification and biodiversity - Ecosystem service management. Ecology Letters, 8, 857-874.

Tscharntke, T., Tylianakis, J. M., Rand, T. A., Didham, R. K., Fahrig, L., Batary, P., ... Westphal, C. (2012). Landscape moderation of biodiversity patterns and processes - Eight hypotheses. Biological Reviews of the Cambridge Philosophical Society, 87, 661-685. https://doi. org/10.1111/j.1469-185X.2011.00216.x

Vickery, J., Tallowin, J., Feber, R., Asteraki, E., Atkinson, P., Fuller, R., \& Brown, V. (2001). The management of lowland neutral grasslands in Britain: Effects of agricultural practices on birds and their food resources. Journal of Applied Ecology, 38, 647-664. https://doi. org/10.1046/j.1365-2664.2001.00626.x

Weiner, C. N., Werner, M., Linsenmair, K. E., \& Blüthgen, N. (2011). Land use intensity in grasslands: Changes in biodiversity, species composition and specialisation in flower visitor networks. Basic and Applied Ecology, 12, 292-299. https://doi.org/10.1016/j.baae.2010.08.006

Westphal, C., Bommarco, R., Carré, G., Lamborn, E., Morison, N., Petanidou, T., ... Steffan-Dewenter, I. (2008). Measuring bee diversity in different European habitats and biogeographical regions. Ecological Monographs, 78, 653-671. https://doi.org/10.1890/07-1292.1
Zuur, A. F., leno, E.N., \& Elphick, C. S. (2010). A protocol for data exploration to avoid common statistical problems. Methods in Ecology and Evolution, 1, 3-14. https://doi.org/10.1111/j.2041-210X.2009.00001.x

Zuur, A., leno, E. N., \& Smith, G. M. (2007). Analyzing ecological data. New York, NY: Springer Science \& Business Media.

\section{SUPPORTING INFORMATION}

Additional supporting information may be found online in the Supporting Information section.

How to cite this article: Li P, Kleijn D, Badenhausser I, et al. The relative importance of green infrastructure as refuge habitat for pollinators increases with local land-use intensity. J Appl Ecol. 2020;00:1-10. https://doi.org/10.1111/1365$\underline{2664.13658}$ 